\title{
THE EFFICACY OF DIZYGTHECA KERCHOVEANA AND AZADIRACHTA INDICA EXTRACTS AS A MOLLUSCICIDAL AND SCHISTOSOMICIDAL AGENTS IN MICE
}

\author{
By
}

AZZA M. EL AMIR ${ }^{1}$, ALYAA A. FARID ${ }^{1}$, MARIAM MOHAMED ${ }^{2}$, WAAD RAMADAN ${ }^{2}$, and AYMAN ALI DIAB ${ }^{2 * *}$

Department of Zoology, Faculty of Science, Cairo University ${ }^{1}$, and Faculty of Biotechnology, October University for Modern Sciences and Arts $^{2}$ (MSA), Egypt ('Correspondence: azzaelamir@yahoo.com, https://orcid.org/0000-0003-4457-6899)

\section{Abstract}

In the present study, the effect of methanol extracts of two plant species, Dizygotheca kerchoveana (Maliaceae) and Azadirachta indica (Araliacaea) were tested on the activity of Schistosoma mansoni worms. Efficacy of two plant extracts compared with praziquantel (PZQ) was evaluated in vivo. The results showed that reduction was $90 \%$ in case of PZQ treatment compared to $76.91 \%, 62.64 \%$ after treatment with $D$. kerchoveana and $A$. indica extracts respectively. PZQ recorded highest significant number of dead ova into oogram pattern $(80 \pm 1.80)$ at $5 \mathrm{wk}$ PI. But, good results were obtained by of $D$. kerchoveana and A. indica methanol extracts $(65.00 \pm 4.05 \& 60.60 \pm 3.60$, respectively) at $3 \mathrm{wk}$ PI. Efficacy of the plant extract showed a significant $(\mathrm{P}<0.01)$ reduction in ova to $91-96.20 \%$ in intestine, $83.36-91.24 \%$ in hepatic tissues as compared to PZQ (10-66.50\% \& 1.14-80.64\%, respectively). Reduction in hepatic granuloma diameter at 3 wk PI was significantly $(\mathrm{P}<0.01)$ reduced in group treated with $D$. kerchoveana $(40.43 \%$ \& $38.30 \%)$ as compared to PZQ $(8.70 \% \& 11.7 \%)$. Sera were assayed by ELISA for IgM \& IgG levels. Highly significant $(P<0.01)$ increase in Igs levels in all infected treated or untreated groups was at $3 \mathrm{wk} \& 5 \mathrm{wk}$ PI as compared to normal mice.

Key words: $S$. mansoni, PZQ, methanol plant extracts, Hepatic granuloma, IgM, IgG

\section{Introduction}

Schistosomiasis continues to rank following malaria at the second position of the world's parasitic diseases in terms of the extent of endemic areas and the number of infected people. Three, significant species of Schistosoma, contribute to morbidity and mortality caused in the endemic areas (Abdel-Haadi and Talaat, 2000).

Three distinct syndromes caused by Schistosoma. At first, there is a cercarial dermatitis or swimmer's itch, caused by an acute inflammatory reaction against cercariae, which provoke a rash consisting of round unnoticed erythrematous papules. The second syndrome is Katayama fever, often seen in primary infection associated with the maturation of schistosomula and the egg production at 3-9wk PI (Boros, 1989). Fever, loss of appetite, abdominal pain and weakness are frequent symptoms while diarrhea and marked eosinophilia are common signs (Cheever, 1997).

The main impact on public health is due to chronic infection " $3^{\text {rd }}$ syndrome" at which half of the number of eggs are not excreted, but are trapped in the liver, lung and intestine. These organs become the target of the granulomatous reaction due to soluble egg antigen (SEA) (Dunne and Doenhoff, 1983; Dunne et al, 1992a\&b). The size and the cellular composition of the granuloma may vary according to host species (Weinstock, 1999), organ site (Moore, 1977), phase of evolution or involution of the lesion (Botros, 1986), and immunoregulatory influences (sensitization and modulation) (Hillyer, 1969). The cellular composition of schistosomal granuloma are 50\% eosinophils, 30\% macrophages, $15 \%$ lymphocytes of both $\mathrm{T} \&$ $B$ cell lineage, small members of mast cells and other inflammatory cells (Weinstock, 1988). Antibodies play an essential role in various effector or regulatory mechanisms according to their isotypes. Ghanem et al. (1977) and (Silveira et al, 2002) detected increased $\operatorname{IgG} \& \operatorname{IgM}$ values in acute and chronic human infections with active $S$. $m a$ - 
nsoni, associated mainly with the early stages of infection.

Ismail et al. (Ismail, 1994) reported that PZQ is an antischistosomal effective drug which reduces the egg count significantly in $S$. mansoni infected patients. However, they recorded the evaluation of resistant strains which reduce the effectiveness of such drug. Screening and analyzing natural botanical compounds for their potential activity are among these drugs. Therefore, medicinal plants regained their position in the last two decades as a vital remedy for many diseases (Abo-Madyan et al, 2004; Massoud et al, 2004a; Maryann et al, 1998). Numerous plant species were biologically screened for their antischistosomal and antihelmintic activity in vitro and in vivo (Shuhua et al, 2000; Sheir et al, 2001; Lyddiard et al, 2002; Massoud et al, 2003; Massoud et al, 2004b; Diab et al, 2005; Koko et al, 2005).

This study aimed to evaluate the efficacy of 2 certain medically important plant extracts of $D$. kerchoveana and $A$. indica as schistosomicidal agents and examine their effects on the Igs level in experimental mice.

\section{Materials and Methods}

Biomphalaria alexandrina were collected water canal at Abu-Rawash City, and examined for S. mansoni infective stages. 100 healthy snails (11-13 $\mathrm{mm}$ in size) were kept in glass aquaria $(50 \times 30 \times 20 \mathrm{~cm})$ filled with 15 liter of dechlorinated tap water and provided with pieces of Elodea $\mathrm{sp}$. plant $(15 \mathrm{~cm}$ long) as a site for egg laying and for oxygenation of water. The snails were fed by fresh lettuce sativa leaves. A piece of chalk was added to each container as a calcium source for the snails (Thomas et al, 1974).

Male Swiss Albino mice (six to eight wkold) (weight: $20 \pm 2 \mathrm{gm}$ ), were provided from the experimental animal unit of Theodore Bilharz Research Institute (TBRI). They were maintained under standard laboratory conditions and fed with high protienic diet (24-25\%) and supplied with acidic distilled water (Nessim and Demerdash, 2000). Animal experiments have been carried out ac- cording to the internationally valid guideline and ethical conditions.

PZQ was freshly prepared before use as $2 \%$ suspension in Cremophor-El. At $3 \& 5$ wk PI; the drug was administered orally to mice in a dose of $500 \mathrm{mg} / \mathrm{kg}$ for 2 consecutive days using a blunt stainless steel cannula.

Preparation of plant methanol extract: The whole over ground parts of 2 plants under investigation (D. kerchoveana; Family $\mathrm{Ma}$ liaceae), Orman Garden, Giza) and (A. indica, Family Araliacaea), El Kanater, Egypt) were collected, identified, dried in air, then in an oven at $50^{\circ} \mathrm{C}$ for $2 \mathrm{hr}$ and finally powdered by a mixer. Each plant powder soaked in methanol (70\%) $70 \mathrm{ml}$ absolute methanol $+30 \mathrm{ml}$ dist. water (Sigma, USA) at $25 \pm 1^{\circ} \mathrm{C}$ for $1 \mathrm{wk}$. The solvent was distilled off under vacuum and the crude extract residues were assayed as aqueous solutions. Plant extracts dose was calculated as $200 \mathrm{ppm} /$ mouse for D. kerchoveana or $650 \mathrm{ppm} / \mathrm{mouse}$ for $A$. indica.

Mice infection: Swiss albino CD1 mice were infected with $S$. mansoni cercariae by tail immersion with $(100 \pm 5)$ cercariae of the Egyptian strain of $S$. mansoni supplied from the SBSP, TRBI. Glass bottles were filled with dechlorinated water at $25 \pm 2{ }^{\circ} \mathrm{C}$ containing 100 cercariae. The tails of mice were immersed for $2-4 \mathrm{hr}$ to ensure maximal cercarial penetration (Fenwick et al, 2006).

Experimental design: 165 mice were divided into 11 groups (15 mice each), 4 of them were normal, and the other 7 groups were exposed to cercarial infection. The groups were planned as the following: G1: Normal mice, G2: Normal mice treated with PZQ as 2 consecutive doses (500 mg/kg each), G3: Normal mice treated with $D$. kerchoveana (200 ppm/ mouse) day after day for 2 successive wk., G4: Normal mice treated with A. indica $(650 \mathrm{ppm})$ day after day for 2 successive wk., G5: Infected untreated mice, G6: Infected mice treated with PZQ as 2 consecutive doses $(500 \mathrm{mg} / \mathrm{kg}$ each $)$ at $3 \mathrm{wk}$ PI., G7: Infected mice treated with PZQ as 2 consecutive doses $(500 \mathrm{mg} / \mathrm{kg}$ each) at $5 \mathrm{wk}$ 
PI, G8: Infected mice treated with D. kerchoveana (200ppm) at 3wk PI, day after day for 2 successive wk, G9: Infected mice treated with $D$. kerchoveana $(200 \mathrm{ppm})$ at 5 wk PI, day after day for 2 successive wk, G10: Infected mice treated with $A$. indica (650ppm) at $3 \mathrm{wk}$ PI, day after day for 2 successive wk and G11: Infected mice treated with $A$. indica $(650 \mathrm{ppm})$ at $5 \mathrm{wk}$ PI, day after day for 2 successive wk. All groups were sacrificed at $8 \mathrm{wk}$ PI and assayed for parasitological, histological and immunological assays.

Determination of worm load by hepatic and mesenteric perfusion: Mice were sacrificed by cervical dislocation. Animals were skinned out and their bodies were washed with tap water and fixed to dissecting board. The abdominal muscles and thoracic ribs were removed. For hepatic perfusion, the needle connected to the automatic pipetting machine was inserted through the inferior vena cava and the liver washed with perfusate buffer $(145 \mathrm{mM} \mathrm{NaCl}, 25 \mathrm{mM} \mathrm{Na}$ citrate). After removing, the portal venous ligature, the needle descended through thoracic aorta. Coils of intestine were gently manipulated to relieve twisting and proper washing of the vessels. The collected worms were coming out with the perfusate. Males, females or couples bulk were collected in conical flasks and then were counted either by direct visualization or under a stereomicroscope.

Egg developmental stages percentage (Oo gram pattern): After perfusion, the intestine was removed and its contents were removed. Three parts $(1 \mathrm{~cm}$ length) from the middle part of small intestine were cut, dried on a filter paper and placed between a slide and cover slide. The preparation was strongly

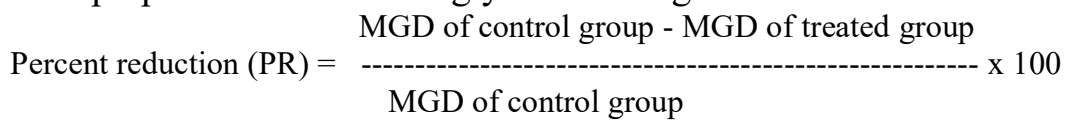

Evaluation of serum IgG and IgM levels using ELISA: Sera of normal control, infected untreated and infected treated mice were collected for ELISA (Engvall and Perlman, 1971). Coaster flat bottom high binding compressed using a thumb (Pellegrino et al, 1962). Hundred eggs were counted in each fragment (3fragments/animal). Viable eggs were counted and classified according to their developmental stages. Embryo occupies one-third the egg diameter (Stage I), one-half (Stage II), two-third (Stage III), embryo occupies the entire egg shell (Stage IV), mature egg which contains a fully developed miracidium and the dead ova appeared as semitransparent granular and darkened with retracted embryo.

Tissue egg load (Eggs/gm tissue): At the end of the perfusion, a piece of liver and intestine were taken to find out the number of eggs/gm in both tissues. Pieces were washed with saline and weighed. Each piece was placed in $5 \mathrm{ml}$ of $5 \% \mathrm{KOH}$ solution (Cheever, 1968; Kamel et al, 1977) incubated at $37^{\circ} \mathrm{C}$ for $24 \mathrm{hr}$ until the tissues were digested. The digested tissues were well shaken and three samples each of $0.25 \mathrm{ml}$ were pipetted on counting slides. Number of ova was counted in three samples and the average was multip- lied by $\mathrm{KOH}$ vol. and divided by the tiss- ue weight to get the number of eggs/gm liver or intestine.

Histopathological study: A lobe of liver was fixed in $10 \%$ formalin and embedded in paraffin wax (Sigma, USA). Sections of 5 $\mu \mathrm{m}$ were stained with Ehrlich's hematoxylin and counter stain with eosin. Five slides/ animal and 3 sections/slide/group were prepared. Individual granulomas with single egg in the center were selected for measurement using a calibrated ocular micro-meter. The mean granuloma diameter (MGD)/ group were calculated for about 140 lesions. PR of MGD/treated group was calculated according to the formula:

plates (Cambridge, MA, USA), were coated with $100 \mu \mathrm{l} /$ well of soluble egg antigen (SEA, given by immunology lab, TBRI, Giza, Egypt) in carbonate/bicarbonate buffer and overnight incubated at $4^{\circ} \mathrm{C}$. Plates were 
incubated for $1 \mathrm{hr}$ at room temperature with $200 \mu 1 /$ well of blocking buffer and washed 5 times with PBS/T. $100 \mu 1 /$ well of diluted sera $(1: 250)$ were added in duplicate and incubated for $1 \mathrm{hr}$ at room temperature with 100 $\mu 1 /$ well of anti-mouse HRP conjugate diluted 1:1000. Plates were washed with PBS/T and incubated with $100 \mu 1 /$ well OPD substrate for 15-30min. at room temperature. Reaction was stopped by stopper buffer $50 \mu 1 /$ well. Absorbance was read at $405 \mathrm{~nm}$ using ELISA reader (Lab. System, Helsinki, Finland).

Statistical analysis: Data was analyzed by ANOVA test to compare the differences between mean values of experimental and control values. Results were expressed as mean \pm standard deviation (SD) and values $\mathrm{P}<0.05$ were significant.

\section{Results}

In the present study, methanol extracts of $D$. kerchoveana and $A$. indica was used on Albino mice infected with $100 \pm 50$ S. mansoni cercariae in comparison to PZQ. (Tab. 1) recorded PR of worm burden. In comparison to infected control group, treatment with PZQ for 5wk PI showed the significant $(P<0.01)$ PR $(90 \%)$, followed by $D$. kerchoveana treated group after only $3 \mathrm{wk}$ PI (76.9\%). At 5wk post treatment, D. kerchoveana has nearly the same PR of $A$. indica extract at both $3 \& 5 \mathrm{wk}$ PI $(66.35 \%, 67.80 \%$ and $62.64 \%$, respectively).

Table 1: Effect of 70\% methanol extract of D. kerchoveana, A. indica plants and PZQ on PR of S. mansoni adults.

\begin{tabular}{|c|c|c|}
\hline Mice & Worm Load X \pm S.E & Worm Load PR \pm S.E \\
\hline Infected control & $26 \pm 3.00$ & $0 \% \pm 11.54$ \\
\hline PZQ (3 wk) & $8.20 \pm 0.21$ & $68.46 \% \pm 2.56^{\mathrm{b}}$ \\
\hline PZQ (5 wk) & $2.60 \pm 0.23$ & $90.00 \% \pm 8.85^{\mathrm{c}}$ \\
\hline D. kerchoveana (3 wk) & $6 \pm 0.57$ & $76.92 \% \pm 9.50^{\mathrm{b}}$ \\
\hline D. kerchoveana $(5 \mathrm{wk})$ & $8.75 \pm 0.77$ & $66.35 \% \pm 8.80^{\mathrm{b}}$ \\
\hline A. indica (3 wk) & $8.38 \pm 0.65$ & $67.79 \% \pm 7.76^{\mathrm{b}}$ \\
\hline A. indica (5 wk) & $9.71 \pm 1.23$ & $62.64 \% \pm 12.67^{\mathrm{b}}$ \\
\hline
\end{tabular}

Significantly different from infected control ${ }^{\mathrm{a}} \mathrm{P}<0.05,{ }^{\mathrm{b}} \mathrm{P}<0.01,{ }^{\mathrm{c}} \mathrm{P}<0.001$

Ovicidal activity and maturity of eggs compared to infected control $62.30 \pm 5.40$, $33.10 \pm 3.40 \& 4.60 \pm 0.40$ for immature, mature \& dead ova res-pectively. PZQ showed significant reduction of mature ova $(\mathrm{P}<0.01)$ and increasing dead ones $(\mathrm{P}<0.001)$ at $5 \mathrm{wk}$
PI (17.40 $\pm 1.00 \& 80 \pm 1.80$, respectively). $D$. kerchoveana and $A$. indica caused early significant $(\mathrm{P}<0.01)$ ova reduction at 3 wk $\mathrm{PI}$, $17.30 \pm 1.73,22.10 \pm 1.39 \& 60.60 \pm 3.60$ for D. kerchoveana and $12 \pm 2.68,23 \pm 3.26 \&$ $65 \pm 4.05$ for $A$. indica, respectively.

Table 2: Effect of $70 \%$ methanol extract of D. kerchoveana, A. indica plants and PZQ on oogram pattern of S. mansoni.

\begin{tabular}{|c|c|c|c|}
\hline \multirow{2}{*}{ Mice Groups } & \multicolumn{3}{|c|}{ Oogram pattern (\% Ova) } \\
\cline { 2 - 4 } & Immature ova $\mathrm{X} \pm$ S.E & Mature ova $\mathrm{X} \pm$ S.E & Dead ova $\mathrm{X} \pm$ S.E \\
\hline Infected control & $62.30 \pm 5.40$ & $33.10 \pm 3.40$ & $4.60 \pm 0.40$ \\
\hline PZQ (3 wk) & $15 \pm 3.10^{\mathrm{b}}$ & $40 \pm 2.90$ & $45 \pm 2.50^{\mathrm{b}}$ \\
\hline PZQ (5 wk) & $2.60 \pm 1.50^{\mathrm{c}}$ & $17.40 \pm 1.00^{\mathrm{b}}$ & $80 \pm 1.80^{\mathrm{c}}$ \\
\hline D. kerchoveana $(3 \mathrm{wk})$ & $17.30 \pm 1.73^{\mathrm{b}}$ & $22.10 \pm 1.39^{\mathrm{a}}$ & $60.60 \pm 3.60^{\mathrm{c}}$ \\
\hline D. kerchoveana $(5 \mathrm{wk})$ & $25.30 \pm 2.73^{\mathrm{b}}$ & $22.10 \pm 3.36^{\mathrm{a}}$ & $52.60 \pm 5.50^{\mathrm{c}}$ \\
\hline A. indica $(3 \mathrm{wk})$ & $12 \pm 2.68^{\mathrm{b}}$ & $23 \pm 3.26^{\mathrm{a}}$ & $65 \pm 4.05^{\mathrm{c}}$ \\
\hline A. indica $(5 \mathrm{wk})$ & $22 \pm 3.97^{\mathrm{b}}$ & $33 \pm 3.73$ & $45 \pm 4.84^{\mathrm{b}}$ \\
\hline
\end{tabular}

In infected control, PZQ treatment at $3 \mathrm{wk}$ PI, recorded $1.14 \%$ \& $8.30 \%$ reduction in ova/gm count in hepatic and intestinal tissues, respectively. However, the PR increased significantly $(\mathrm{P}<0.01)$ at $5 \mathrm{wk}$ PI to $80.64 \%$ and $66.50 \%$. Treatment of infected mice with each of two plant extracts attained an early (at $3 \mathrm{wk}$ PI) significant $(\mathrm{P}<0.001)$ PR for hepatic and intestinal tissues (ranged from $83.36 \%-91.24 \%$ \& $96.85 \%-91.10 \%$, respectively, in compared to infected control group (Tab. 3). 
Table 3: Effect of methanol extract of D. kerchoveana, A. indica and PZQ on PR of intestinal and hepatic tissues egg in mice.

\begin{tabular}{|c|c|c|c|c|}
\hline \multirow{2}{*}{ Mice } & \multicolumn{2}{|c|}{ Hepatic (Ova Count) } & \multicolumn{2}{c|}{ Intestinal(Ova Count) } \\
\cline { 2 - 5 } & $\mathrm{X} \pm$ S.E & $\mathrm{PR} \pm$ S.E & $\mathrm{X} \pm$ S.E & PR \pm S.E \\
\hline Infected control & $22975 \pm 186.20$ & $0 \% \pm 0.81$ & $35106 \pm 747.50$ & $0 \% \pm 2.13$ \\
\hline PZQ (3 wk) & $22714.70 \pm 747.50$ & $1.14 \% \pm 3.29$ & $32167.90 \pm 747.50$ & $8.37 \% \pm 0.08^{\mathrm{a}}$ \\
\hline PZQ (5 wk) & $4450 \pm 747.50$ & $80.64 \% \pm 16.80^{\mathrm{c}}$ & $11750 \pm 747.10$ & $66.53 \% \pm 6.36^{\mathrm{b}}$ \\
\hline D. kerchoveana (3 wk) & $2014.30 \pm 234.50$ & $91.23 \% \pm 11.64^{\mathrm{c}}$ & $3128 \pm 585.40$ & $91.10 \% \pm 18.71^{\mathrm{c}}$ \\
\hline D. kerchoveana (5 wk) & $3825 \pm 400.22$ & $83.35 \% \pm 10.46^{\mathrm{c}}$ & $3212.50 \pm 469.60$ & $90.85 \% \pm 14.62^{\mathrm{c}}$ \\
\hline A. indica (3 wk) & $2442.90 \pm 407.44$ & $89.37 \% \pm 16.68^{\mathrm{c}}$ & $1357.14 \pm 86.90$ & $96.13 \% \pm 6.40^{\mathrm{c}}$ \\
\hline A. indica (5 wk) & $3128.57 \pm 713.71$ & $86.38 \% \pm 23.00^{\mathrm{c}}$ & $2771.43 \pm 489.60$ & $92.11 \% \pm 17.66^{\mathrm{c}}$ \\
\hline
\end{tabular}

PR in hepatic granuloma diameter of infected treated groups compared to infected controls, PZQ recorded a mild but significant $(\mathrm{P}<0.05)$ PR at 3 \& $5 \mathrm{wk}$ PI $(8.70 \%$ $\& 11.74 \%$, respectively). D. kerchoveana treatment induced highly significant $(\mathrm{P}<0.01)$

PR as early as $3 w k$ PI and decreased by only $2 \%$ at $5 \mathrm{wk}$ PI. Also, treatment of infected mice with $A$. indica extract significantly $(\mathrm{P}<0.01)$ reduced the granuloma diameter by $38.26 \% \& 21.74 \%$ at $3 \& 5 \mathrm{wk}$ PI, respectively (Tab. 4).

Table 4: Effect of 70\% methanol extract of D. kerchoveana, A. indica plants and PZQ on PR of granuloma diameter.

\begin{tabular}{|c|c|c|}
\hline \multirow{2}{*}{ Mice Groups } & \multicolumn{2}{|c|}{ Granuloma diameter } \\
\cline { 2 - 3 } & $\mathrm{X} \pm \mathrm{S} . \mathrm{E}$ & $\mathrm{PR} \pm \mathrm{S} . \mathrm{E}$ \\
\hline Infected control & $230 \pm 5.10$ & $0 \% \pm 2.21$ \\
\hline PZQ (3wk) & $210 \pm 4.19$ & $8.70 \% \pm 1.99^{\mathrm{a}}$ \\
\hline PZQ (5wk)) & $203 \pm 3.90$ & $11.74 \% \pm 1.92^{\mathrm{a}}$ \\
\hline D. kerchoveana (3wk) & $137 \pm 1.95$ & $40.43 \% \pm 1.42^{\mathrm{b}}$ \\
\hline D. kerchoveana (5wk) & $142 \pm 2.50$ & $38.26 \% \pm 1.76^{\mathrm{b}}$ \\
\hline A. indica (3wk) & $150 \pm 2.90$ & $34.78 \% \pm 1.93^{\mathrm{b}}$ \\
\hline A. indica (5wk) & $180 \pm 3.40$ & $21.74 \% \pm 1.88^{\mathrm{b}}$ \\
\hline
\end{tabular}

Significantly different from infected control ${ }^{a} P<0.05,{ }^{b} P<0.01,{ }^{c} P<0.001$

Infection caused a significant $(\mathrm{P}<0.01)$ increase in Igs levels $(1.40 \pm 0.30 \& 1.10 \pm$ 0.25 , respectively) compared to normal serum levels $(0.30 \pm 0.15,0.30 \pm 0.20$ for IgM \& $\mathrm{IgG}$, respectively). PZQ has no effect on Igs levels of infected mice sera compared to infected control. D. kerchoveana and A. indica extracts attained a slight modification of infection as increasing IgM level $(1.38 \pm 0.20$ to $1.50 \pm 0.20)$. But, treatment with both plant extracts success to modulate immune system by a significant $(P<0.05)$ decrease in IgG level ranged from $0.84 \pm 0.19$ to $0.99 \pm 0.20$ at 3 \& 4 wk PI, respectively (Tab. 5).

Table 5: Effect of 70\% methanol extract of D. kerchoveana, A. indica plants \& PZQ on levels of IgM \& IgG in mice.

\begin{tabular}{|l|l|l|}
\hline Mice Groups & IgM X \pm S.E & IgG X \pm S.E \\
\hline Normal control & $0.31 \pm 0.08$ & $0.30 \pm 0.12$ \\
\hline PZQ & $0.37 \pm 0.06$ & $0.38 \pm 0.27$ \\
\hline D. kerchoveana & $0.29 \pm 0.02$ & $0.30 \pm 0.17$ \\
\hline A. indica & $0.36 \pm 0.16$ & $0.37 \pm 0.26$ \\
\hline Infected control & $1.40 \pm 0.31^{\mathrm{c}}$ & $1.10 \pm 0.25^{\mathrm{c}}$ \\
\hline Infec.\& PZQ (3 wk) & $1.10 \pm 0.21^{\mathrm{c}}$ & $1.10 \pm 0.19^{\mathrm{c}}$ \\
\hline Infec.\& PZQ (5 wk) & $1.50 \pm 0.22^{\mathrm{c}}$ & $1.10 \pm 0.21^{\mathrm{c}}$ \\
\hline Infec.\& D. kerchoveana (3 wk) & $1.50 \pm 0.20^{\mathrm{c}}$ & $0.84 \pm 0.20^{\mathrm{c}}$ \\
\hline Infec.\& D. kerchoveana (5 wk) & $1.38 \pm 0.20^{\mathrm{c}}$ & $0.86 \pm 0.20^{\mathrm{c}}$ \\
\hline Infec.\& A. indica (3 wk) & $1.40 \pm 0.23^{\mathrm{c}}$ & $0.89 \pm 0.18^{\mathrm{c}}$ \\
\hline Infec.\& A. indica (5 wk) & $1.50 \pm 0.20^{\mathrm{c}}$ & $1 \pm 0.21^{\mathrm{c}}$ \\
\hline
\end{tabular}

\section{Discussion}

Schistosomiasis is not only a national hea1th problem, but also a world one calling for international cooperation (Mc-Manus et al, 2018). Araliacaea, Maliaceae, Asteraceae, Compositae and Euphorbiaceae extracts proved to have molluscicidal, miracicidal, cer- caricidal, and killed S. mansoni (Abdel Ghaffar et al, 2008). In the present study, highly potent extracts were obtained from $D$. kerchoveana and A. indica. Ismail et al. (1996) reported that PZQ was effective an antischistosomal drug for $S$. mansoni and reduced egg count significantly in patients. In 
the present study, treatment of $S$. mansoniinfected mice with either PZQ chemotherapy or methanol extracts of $D$. kerchoveana and $A$. indica showed that potency of plant extracts, more than PZQ with a significant $(\mathrm{P}<0.01) \mathrm{PR}$ of in worm burden $(90 \%)$ at 5wk PI. D. kerchoveana treatment gave PR less than that of PZQ (76.90\%), after only 3 wk PI which was very important in disease control. Andrews (1978) found that PZQ in $S$. mansoni mice infected delayed hatching of excreted eggs for $24 \mathrm{hr}$. Richard et al. (1983) reported that PZQ was lethal to $S$. mansoni eggs, in host tissues in high doses. El Shenawy et al. (2006) used crude extract of Cleome droserifolia leaves on S. mansoni infected mice, found weak reduction in worm burden $(32.4 \%)$, but increase of dead eggs, and suppressive effect on granulomas. Methanolic leaf extract of Jatro-pha curcas caused S. mansoni reduction of $8.33 \%$, but PZQ gave 97\% (Adamu et al, 2006).

In the present study, PZQ gave as high percentage $(80 \%)$ of dead ova. D. kerchoveana and $A$. indica extracts significantly decreased the number of mature ova, increase the percentage of dead ova and reduced granuloma diameter after 3 wk PI. But, PZQ did not reduce the ova count in hepatic or intestinal tissues at $3 \mathrm{wk}$ PI $(1.14 \& 10 \%$, respectively), compared to $(\mathrm{P}<0.01) \mathrm{PR}$ of $D$. kerchoveana and A. indica extracts $(66.5 \%$ \& $80.64 \%$, respectively), with highly significant $(\mathrm{P}<0.001)$ increase in PR by 5wk PI (96.20-91\% \& 83.36-91.24\%, respectively). These agreed with Ahmed and Rifaat (2005) who detected that ethanolic extract of Solanum nigrum decreased schistosome eggs in mice hepatic tissue. Also, Koko et al. (2005) found a significant reduction in egg count/ gm feces, and/count in tissue \& recovery of S. mansoni adult mice with Balanites aegyptiaca fruits. Boros (1989) found the vigorous granulomatous response rather than direct action of egg antigen(s) for pathologic tissue in schistosomiasis. Liver granulomas induce particularly high levels of inflammatory mediators (Selim et al, 2014). Reduc- tion in M.G.D. caused by both plant extracts may be due to reducing effects on mediators, macrophages and eosinophils, also to its hepatoprotective effect and inhibitory effect on oogram pattern. PZQ had a moderate effect on granuloma PR after 5wk PI, but PZQ has a week effect on inflammatory mediator's level with a number of worms and eggs at infection time (Botros et al, 2000; 2006). This agreed with Massoud et al. (2000c; 2005) studied effect of Myrrh on S. mansoni-infected mice liver, with marked reduction of granulomas number and size and significant reduction in collagen content deposition in portal areas and around central veins proving its efficiency.

The effect of Daucus carota extracts on immune responses of $S$. mansoni infected mice was studied. The rate of reduction in worm in mice injected with some fractions indicated a strong protection. Some extracts induced humoral immune response by raising IgG level at 2, $4 \& 6 \mathrm{wk}$ PI as compared with infected control. Phenotypic analysis of the cellular immune response in spleen and mesenteric lymph nodes was accomplished by direct immunofluorescence. Some extracts stimulated the blastogenesis of $\mathrm{CD}^{+}$ $\mathrm{T}$ splenocytes and mesenteric lymph node cells (Shalaby et al, 1999). Total IgE was significantly higher in Fasciola and Schistosoma patients before treatment compared to control and decreased significantly with Myrrh oleo-gum. IL-1 beta \& IL-5 were high in fasciolosis and schistosomiasis, but decreased with therapy. Depressed IL-4 production was a parasite immune evasion or host regulatory mechanism \& cytokines levels as cure criteria (Massoud et al, 2000b).

Immunomodulatory effects of iridoid mixture, iridoid-treated $S$. mansoni homogenate on mice were measured by IgM \& IgG levels against soluble $S$. mansoni antigenic preparation (SWAP) antigens by ELISA. Cellular immune responses calculated mean of $\mathrm{CD}^{+}, \mathrm{CD}^{+} \mathrm{T}$, B-mesenteric lymph node cells (MLNC) \& $\mathrm{CD}^{+}, \mathrm{CD}^{+} \mathrm{T}$ thymocytes by direct immunofluorescence staining in 
treated mice as compared to untreated homogenate given mice or untreated mice. $1^{\text {st }} \&$ $2^{\text {nd }}$ immunizations with iridoid mixture treated homogenate caused significantly elevated $(\mathrm{P}<0.05) \operatorname{IgM} \& \operatorname{IgG}$ against the antigen compared with sera from control mice. Immunized with homogenate treated with iridoid mixture gave a significant increase in $\mathrm{CD}^{+} \mathrm{T}$ thymocytes, no significant increase in $\mathrm{CD}^{+} \mathrm{T}$ thymocytes, a significant increase in $\mathrm{CD}^{+} \mathrm{T}$ lymphocytes (MLNC), without significant increase in $\mathrm{CD}^{+} \mathrm{T} \& \mathrm{~B}$ lymphocytes compared with mice immunized with untreated homogenate or non-treated normal mice (Bahgat et al, 2005).

\section{Conclusion}

PZQ $\mathrm{t}$ showed no effect on Igs picture. $D$. kerchoveana and $A$. indica extracts gave im munomodulating effects by increasing IgM level at 3 wk PI. D. kerchoveana and $A$. indica extracts caused $S$. mansoni eradication and enhanced reduction in inflammatory granuloma reaction around eggs as a result of the increased diminution in the Igs level. Thus, $D$. kerchoveana and $A$. indica extracts are promising antischistosomal drugs.

Conflicts of interest: The authors declared that they have neither conflict of interest nor received fund.

\section{References}

Abdel Ghaffar, F, Bakry, FA, Ahmed, F, 2008: Efficacy of six plant species molluscicidal on infection of Biomphalaria alexandrina snails to Schistosoma mansoni. Proc. Zool. Soc. J. AR Egypt 9:13-7.

Abdel-Haadi, AM, Talaat, M, 2000: Histopathological assessment of tissue repair after treatment of human schistosomiasis. Act. Trop. 77: 91-6.

Abo-Madyan, AA, Morsy, TA, Motawea, SM, Morsy, ATA, 2004: Clinical trial of Mirazid ${ }^{\mathbb{B}}$ in treatment of human fascioliasis in Ezbet ElBakly (Tamyia Center) Al-Fayoum Governorate. J. Egypt. Soc. Parasitol. 34, 3:807-18.

Adamu, SU, Kela, SL, Suleiman, MM, 2006:

Antischistosomal properties of extracts of Jatropha curcas on $S$. mansoni infection in mice. Afr. J. Trad. Compl. Alter. Med. 3:37-41.

Ahmed, AH, Rifaat, MM, 2005: Effects of $S$. nigrum leaves water extract on the penetration and infectivity of $S$. mansoni cercariae. J. Egypt Soc. Parasitol. 35, 1:33-40.

Akpom, CA, Warren, KS, 1975: Calorie and protein malnutrition chronic in murine schistosomiasis mansoni: Effect on the parasite and the host. J. Infect. Dis.132:6-14.

Andrews, P, 1978: Effect of PZQ on free living stages of S. mansoni. Z. Parsitenk. 56:99-106. Bah, S, Diallo, D, Dembélé, S, Paulsen, BS, 2006: Ethnopharmacological survey of plants used for treatment of schistosomiasis in Nio-no District, Mali. J. Ethnopharmacol. 105:387-99.

Bahgat, M, Shalaby, NM, Ruppel, A, Maghraby, AS, 2005: Humoral and cellular immune response induced in mice by purified iridoid mixture that inhibits penetration of $S$. mansoni cercariae upon topical treatment of mice tails. J. Egypt Soc. Parasitol. 35, 3:597-613.

Boros, DL, 1989: Immunopathology of S. mansoni infection. Clin. Microbiol. Rev. 2:250-69.

Botros, SS, El-Badrawy, N, El-Raziky, EH, 1986: Subcutaneous implantation of the spleen as a new technique for experimental induction of hepatic Schistosoma mansoni egg granulomas. Trans. Roy. Soc. Trop. Med. Hyg. 80:515-6

Botros, SS, Mahmoud, M, Hammam, O, Salah, F, Zidek, Z, et al, 2006: Effect of adamantylamide dipeptide as adjuvant therapy to praziquantel in mice infected with different $S$. mansoni isolates. APMIS. 114: 480-91.

Botros, SS, Sabra, AN, Kamel, M, Nagy, F, El-Beih, N, et al, 2000: Assessment of combineed therapy of recombinant glutathione S-transferase 26 \& praziquantel on immuno-parasitologic responses. Arzneimittelforschung. 50:929-35.

Cheever, AW, 1968: Conditions affecting the accuracy of potassium hydroxide digestion technique for counting $S$. mansoni eggs in tissue. Bull. WLD Hlth. Org. 39: 328-31.

Cheever, AW, Yap, GS. 1997: Immunologic basis of disease and disease regulation in schistosomiasis. Chem. Immunol. 66: 154-76.

Diab, TM, El-Nahas, HA, Abdel-Hamed, E, et al, 2005: Bioactivity of certain Egyptian plant extracts as antishistosomiasis mansoni agents (a pilot study). Egypt. J. Med. Sci. 26:383-95.

Dunne, D, Butterworth, A, Fulford, A, Kariuki, H, Langley, J, et al, 1992: Immunity after treatment of human schistosomiasis: Association between IgE antibodies to adult worm antigens and resistance to reinfection. Eur. J. Immunol. 22:1483-94. 
Dunne, DW, Butterworth, AE, Fulford, AJ, Ouma, JH, Sturrock, RF, 1992: Human IgE responses to $S$. mansoni and resistance to reinfection. Mem. Inst. Oswaldo Cruz. 87:99-103.

Dunne, DW, Doenhoff, MJ. 1983: Schistosoma mansoni egg antigens and hepatocytes damage in infected T-cell- deprived mice. Centr. Microbiol. Immunol. 7: 22-9.

EL Shenawy, N, Soliman, M, Ismail, M, Abdul-Nabi, A, 2006: Does Cleome droserifolia have antishistosomiasis mansoni activity? Rev. Inst. Med. Trop. S. Paulo 48:223-8.

Engvall, E, Perlman, P, 1971: Enzyme linked immunosorbent assay: Quantitative assay of IgG. Immunochemistry 8:871-4.

Ghanem, MH, El-Hawary, MFS, Issa, IA, Wafy, AA, Abd-El-Aziz, O, et al, 1977: Serum Igs in different stages of human intestinal schistosomiasis. J. Egypt Med. Assoc. 60:231-42.

Hillyer, GE, 1969: Immunoprecipitin S. mansoni infections. Exp. Parasit. 25: 376-9.

Ismail, M, Metwally, AA, Farghally, A, Bennett, J, 1996: Characterization of isolates of $S$. mansoni from Egyptian villagers that tolerate high doses of PZQ. Am. J. Trop. Med. Hyg. 55: 214-8.

Kamel, IA, Cheever, AW, Elwi, AM, Mosmann, JE, Danner, R, 1977: Schistosoma mansoni and Schistosoma haematobium infections in Egyptian technique for recovery of worms at necropsy. Am. Trop. Med. Hyg. 26:696-701.

Koko, WS, Abdalla, HS, Galal, M, Khalid, H, 2005: Evaluation of oral therapy on $S$. mansoni $u$ sing single dose of Balanites aegyptiaca fruits and Praziquantel. Fitoterapia 76:30-4.

Llegrino, J, Oliveria, CA, Faria, J, Cunha, A, 1962: New approach to the screening of drugs in exp. S. mansoni in mice. Am. J. Trop. Med. Hyg. 11: 201-5.

Lyddiard, JR, Whitfield, PJ, Barlett, A, 2002: Antischistosomal bioactivity of isoflavonoids from Millettia thonningii (Leguminosae). J. Parasitol. 88:163-70.

Maryann, O, David, K, Fanell, F, Kemper, K A, 1998: A Review of 12 commonly used medicinal herbs. Arch. Fam. Med. 7:523-36.

Massoud, AMA, Morsy, TA, Haridy, FM, 2003: Treatment of Egyptian dicrocoeliasis in man and animals with mirazid. J. Egypt. Soc. Parasitol. 33, 2:437-42.

Massoud, AM, El Ebiary, FH, Abd El Salam, NF, 2004a: Effect of myrrh extract on liver of normal and bilharzial infected mice: An ultrastructural study. J. Egypt Soc. Parasitol. 34:1-21. Massoud, AM, El-Kholy, N, El-Shennawy, F, Farag, R, 2004b: Study of some immune aspects in patients with fascioliasis before \& after Mirazid treatment. J. Egypt Soc. Parasitol. 34: 315-32.

Massoud, AM, Metwally, DM, Khalifa, KE, Habib, FS, 2004c: Compatibility of B. alexandrina snails to infection with $S$. after exposure to sublethal concentrations of Myrrh. J. Egypt. Soc. Parasitol. 34:995-1008.

Massoud, AM, El-Ebiary, FH, Ibrahim, SH, 2005: Light microscopic study of t effect of new antischistosomal drug (myrrh extract) on the liver of mice. J. Egypt Soc. Parasitol. 35:971-88. McManus, DP, Dunne, DW, Sacko, M, Utzinger, J, Vennervald, BJ, et al, 2018: Schistosomiasis. Nature Rev. Dis. Primers 4:13-8

Moore, DL, Grove, DI, Warren, KS, 1977: Schistosoma mansoni egg granuloma: Quantitation of cell populations. J. Pathol. 121:41-50.

Richard, D, Pearson, M, Richard, L, Guerrant, M, Virginia, C, 1983: Praziquantel: A major advance in antihelmintic therapy: Diagnosis and treatment. Ann. Int. Med. 99:195-8.

Selim, S, El Sagheer, O, El Amir, A, Barakat, R, Hadley, K, et al, 2014: Efficacy and safety of Arachidonic acid for treatment of Schistosoma mansoni-infected children in Menoufia, Egypt. Am. J. Trop. Med. Hyg. 91: 973-81.

Shalaby, NM, Maghraby, AS, El-Hagrassy, A M, 1999: Effect of Dacucus carota var. boissieri extracts on immune response of $S$. mansoni infected mice. Folia Microbiol. 44:441-8.

Sheir, Z, Nasr, AA, Massoud, A, Salama, O, Badra, GA, et al, 2001: A safe, effective, herbal antischistosomal therapy derived from myrrh. Am. J. Trop. Med. Hyg. 65:700-4.

Shuhua, X, Chollet, J, Weiss, NA Berquist, R, Tanner, M, 2000: Preventive effect of artemether in experimental animals infected with Schistosoma mansoni. Parasitol. Int. 49:19-24.

Silveira, AM, Bethony, J, Gazzinelli, A, Kloos, H, Fraga, L, et al, 2002: High levels of Ig G4 to $S$. mansoni egg antigens in individuals with periportal fibrosis. Am. J. Trop. Med. Hyg. 66:542-9.

Weinstock, J, Elliott, D, Metwali, A, Blum, A, Qadir, K, et al, 1999: Immunoregulation within the granulomas of murine Schistosomiasis mansoni. Micro. Infect. 1:491-8. 